Correspondence

Peter S. Zilm

peter.zilm@adelaide.edu.au

Received 8 August 2006

Revised 29 September 2006

Accepted 2 October 2006

\section{The proteomic profile of Fusobacterium nucleatum is regulated by growth $\mathrm{pH}$}

\author{
Peter S. Zilm, ${ }^{1}$ Christopher J. Bagley, ${ }^{2} \ddagger$ Anthony H. Rogers, ${ }^{1}$ lan R. Milne ${ }^{2} \S$ \\ and Neville J. Gully ${ }^{1}$ \\ ${ }^{1}$ Oral Microbiology Laboratory, Dental School, The University of Adelaide, Adelaide, Australia \\ ${ }^{2}$ Protein Core Facility, Hanson Institute, The Institute of Medical and Veterinary Science, \\ Adelaide, Australia
}

\begin{abstract}
Fusobacterium nucleatum is a saccharolytic Gram-negative anaerobic organism believed to play an important role in the microbial succession associated with the development of periodontal disease. Its genome contains niche-specific genes shared with the other inhabitants of dental plaque, which may help to explain its ability to survive and grow in the changing environmental conditions experienced in the gingival sulcus during the transition from health to disease. The $\mathrm{pH}$ of the gingival sulcus increases during the development of periodontitis and this is thought to occur by the metabolism of nutrients supplied by gingival crevicular fluid. In comparison with other plaque inhabitants, F. nucleatum has the greatest ability to neutralize acidic environments. The differential expression of soluble cytoplasmic proteins induced by acidic $(\mathrm{pH} \mathrm{6.4)} \mathrm{or} \mathrm{basic}(\mathrm{pH} 7.4$ and 7.8) conditions, during long-term anaerobic growth in a chemostat, was identified by two-dimensional gel electrophoresis and image analysis software. Twenty-two proteins, found to have altered expression in response to external $\mathrm{pH}$, were identified by tryptic digestion and mass spectrometry. Eight differentially expressed proteins associated with increased energy (ATP) production via the 2-oxoglutarate and Embden-Meyerhof pathways appeared to be directed towards either cellular biosynthesis or the maintenance of internal homeostasis. Overall, these results represent the first proteomic investigation of $F$. nucleatum and the identification of gene products which may be important in the organism's persistence during the transition from health to disease in vivo.
\end{abstract}

\section{INTRODUCTION}

Periodontal disease is widespread amongst the human population and has a complex polymicrobial aetiology; its progression is associated with inflammation leading to tissue and alveolar bone destruction. The composition of microbial consortia is not uniform between subgingival sites, or from subject to subject (Haffajee \& Socransky, 2005; Slots, 2005), and may involve around 700 different species together with some viruses (Haffajee \& Socransky, 2006). The study of the complex interrelationships associated with the onset of disease has resulted in the identification of six bacterial clusters based on the role and distribution of species isolated from disease sites (Holt \& Ebersole, 2005). It is evident that the composition of the subgingival microbiota varies between periodontally healthy and diseased

†Present address: Adelaide Proteomics Centre, Hanson Institute, Adelaide, Australia.

$\ddagger$ Present address: Department of Medicine, The University of Adelaide, Adelaide, Australia.

§Present address: Toxicology, Division of Clinical Biochemistry, The Institute of Medical and Veterinary Science, Adelaide, Australia.

Abbreviation: TCEP, tris-(2-carboxyethyl)phosphine hydrochloride. sites; the diseased site climax community results from both autogenic and allogenic succession of certain bacteria derived from the healthy climax community (Haffajee \& Socransky, 1994; Socransky \& Haffajee, 2005). One of the many changes is the increased prevalence of a limited set of species, particularly fermentative Gram-negative anaerobes that make up the 'red and orange complex' and which are considered to be periodontal pathogens. The red complex, considered to be the most important pathogens, consists of Porphyromonas gingivalis, Tannerella forsythia and Treponema denticola. The orange complex includes species whose numbers are elevated in periodontitis but whose contribution to disease remains unclear. Members of this group include several Fusobacterium species, together with Prevotella and Peptostreptococcus species (Holt \& Ebersole, 2005; Socransky \& Haffajee, 2005; Socransky et al., 1998).

The transition from a 'healthy' to a 'disease-associated' subgingival microbiota can be affected by a number of allogenic factors including $\mathrm{pH}$, oxygen levels, temperature, osmotic pressure and oxidation-reduction potential (Haffajee \& Socransky, 2005). During the onset of periodontitis, the $\mathrm{pH}$ of the periodontal pocket increases with 
pocket depth and the severity of the inflammatory host response (Kung et al., 1990; Mikasaki, 2006).

Fusobacterium nucleatum, which has been associated with many polymicrobial anaerobic infections (Brook, 2002) is, as already noted, a member of the so-called 'orange complex'. It binds to epithelial cells (Han et al., 2000; Edwards et al., 2006) and appears to play a pivotal role in plaque biofilm development, since it also co-aggregates with both early and late colonizers (Shaniztki et al., 1997; Kolenbrander \& London, 1993). Based on the 'Ecological Plaque Hypothesis' of Marsh (1991, 1994), F. nucleatum has been described as an initiator organism promoting changes in the gingival sulcus and allowing acid-sensitive pathogenic successors to establish and proliferate.

Takahashi (2005) has proposed an order of microbial succession in which the saccharolytic organisms, $F$. nucleatum and Prevotella intermedia, initially colonize the shallow periodontal pocket. During these early stages, the $\mathrm{pH}$ of the pocket may be acidic but the metabolism of nutrients (mainly host proteins) supplied by gingival crevicular fluid (GCF) promotes the establishment of a neutral environment (Bickel \& Cimasoni, 1985). The rise in localized $\mathrm{pH}$ then allows acid-sensitive and more proteolytic species, such as Porphyromonas gingivalis, to colonize. The destruction of host tissues and increased efflux of GCF caused by the proliferation of the so-called 'red complex' group of bacteria (Holt \& Ebersole, 2005) leads to an increase in the fermentation of amino acids into organic acids and ammonia, producing the rise in $\mathrm{pH}$ above neutrality. The $\mathrm{pH}$ range of the gingival sulcus has been reported to vary between 6.5 and 8.5 , and increased pocket depth and inflammation have been correlated with increased alkalinization (Bickel \& Cimasoni, 1985). A wide variation in the external $\mathrm{pH}$ can be considered to be one of many challenges encountered by F. nucleatum if it is to survive and grow in the gingival sulcus. Takahashi (2003) examined the acid-neutralizing capability of $F$. nucleatum, Porphyromonas gingivalis and Prevotella intermedia and concluded that, at a starting $\mathrm{pH}$ of 5-5.5, F. nucleatum had the highest acid-neutralizing activity.

In the present study, we investigated the change in cytoplasmic protein expression by $F$. nucleatum subsp. polymorphum in response to external growth $\mathrm{pH}$. Proteomic investigations have proved difficult when using traditional batch cultivation of bacteria because the dynamic physicochemical conditions taking place produce complex data which are difficult to interpret (Hoskinsson \& Hobbs, 2005). In consideration of these factors, we have used continuous culture in a chemostat, a technique which has become increasingly useful in the post-genomic era to study global changes in cellular physiology. The advantages of this technique for functional genomic studies have recently been reviewed (Hoskinsson \& Hobbs, 2005).

The recent advances in functional genomics have meant that the roles of genes in microbial physiology can be studied at multiple levels. Unlike transcriptome analysis, using fullgenome micro-arrays, global protein (proteomic) analysis may be considered a true measure of cellular functionality.

We have investigated expression of cytoplasmic proteins by $F$. nucleatum at different external growth pHs. The experimental conditions used allowed coverage of a subset of the F. nucleatum proteome and, to our knowledge, this is the first proteomic investigation of this organism. The information gained may help in understanding the longterm adaptation to $\mathrm{pH}$ stress and provide an insight into how this important organism proliferates within the gingival sulcus during the transition from health to disease.

\section{METHODS}

Materials and reagents. Amino acids, endonucleases, TCEP (tris(2-carboxyethyl)phosphine hydrochloride), HPLC water and Bacterial Protease Inhibitor Cocktail were purchased from Sigma Aldrich. All 2D-PAGE chemicals, IPG strips, IEF equipment, and densitometer and image analysis software used for proteomic analysis were purchased from Bio-Rad. Brain Heart Infusion broth and anaerobic blood agar plates were purchased from Oxoid.

Micro-organism. Fusobacterium nucleatum ATCC 10953, subsp. polymorphum (Dzink et al., 1990) was maintained on anaerobic blood agar plates, following growth at $37^{\circ} \mathrm{C}$ in an atmosphere of $\mathrm{N}_{2} / \mathrm{CO}_{2} / \mathrm{H}_{2}$ (90:5:5, by vol.). Starter cultures $(200 \mathrm{ml})$ were grown in Brain Heart Infusion broth and, after overnight incubation, were used for chemostat inoculation. Following inoculation, cultures were allowed to reach mid-exponential phase before switching on the medium pump to allow continuous culture.

Growth media and culture conditions. F. nucleatum was grown anaerobically using a model C30 BioFlo Chemosat (New Brunswick Scientific) with a culture volume of $365 \mathrm{ml}$ as described previously (Rogers et al., 1991). Bacterial growth rates (generation times of 7-12 h) are typical of natural ecosystems such as dental plaque (Socransky et al., 1977), and previous studies (Hamilton et al., 1979) have shown that bacterial metabolic properties are often quite different when the organism is growing near its maximum growth rate $\left(\mu_{\max }\right)$. At steady state, the specific growth rate $(\mu)$ is considered to be equal to the dilution rate $(D)$ of growth medium into the culture vessel. Using the relationship $T_{\mathrm{g}}=\ln 2 / D$, where $T_{\mathrm{g}}$ is the generation time, the medium flow rate was set at $27.5 \mathrm{ml} \mathrm{h}^{-1}\left(D=0.075 \mathrm{~h}^{-1}\right)$, which gave an estimated $T_{\mathrm{g}}$ of $9.2 \mathrm{~h}$. This growth rate was chosen as it equates to the expected growth rates of plaque bacteria in vivo, and we have reported previously (Rogers et al., 1991) that at low growth rates, $T_{\mathrm{g}}=14-7 \mathrm{~h}\left(D=0.05\right.$ and $D=0.1 \mathrm{~h}^{-1}$ respectively), the metabolic properties of F. nucleatum ATCC 10953) did not vary greatly.

Anaerobic conditions were maintained by continually gassing the culture vessel and medium reservoir with a $\mathrm{N}_{2} / \mathrm{CO}_{2}(90: 10, \mathrm{v} / \mathrm{v})$ mixture. Growth $\mathrm{pH}$ was maintained at $6.4,7.2,7.4$ or 7.8 by the automatic addition of $2 \mathrm{M} \mathrm{KOH}$ or $2 \mathrm{M} \mathrm{HCl}$ using a Fermac $260 \mathrm{pH}$ controller (ElectroLab), and it varied by less than $0.2 \mathrm{pH}$ units. Prior to sampling, the culture was allowed to reach steady state; i.e. when consecutive daily optical density and cellular protein measurements varied by less than $5 \%$. This was achieved after about 10 culture volume changes $(130 \mathrm{~h})$. The culture was then sampled over five consecutive days and cell yields were quantified by determining the optical density $(560 \mathrm{~nm})$ and cellular protein concentration as described previously (Zilm et al., 2002). 
The organism was grown under nitrogen limitation in a chemically defined growth medium (CDM); the concentration of the energyyielding amino acids, glutamic acid $(40 \mathrm{mM})$, lysine and histidine (10 $\mathrm{mM}$ each), and glucose $(20 \mathrm{mM})$ were raised to increase growth yields (van der Hoeven et al., 1985).

Cell harvesting. After achieving steady state at each defined growth $\mathrm{pH}, 80 \mathrm{ml}$ cell culture was removed from the culture vessel and immediately cooled on ice to $4{ }^{\circ} \mathrm{C}$. The culture sample was then centrifuged $\left(6000 \mathrm{~g}, 20 \mathrm{~min}\right.$ at $\left.4{ }^{\circ} \mathrm{C}\right)$, washed twice in sodium phosphate buffer $(0.1 \mathrm{M})$ and resuspended in an aliquot of the same buffer before storing at $-80^{\circ} \mathrm{C}$. Samples harvested over 5 consecutive days were pooled.

Analytical techniques. During growth at steady state, cell filtrates were obtained by centrifuging culture samples $(6000 \mathrm{~g}, 10 \mathrm{~min}$ at $4{ }^{\circ} \mathrm{C}$ ) followed by filtration of the supernatant through $0.22 \mu \mathrm{m}$ filters (Durapore, Millipore). Residual levels of amino acids and glucose were measured by methods described previously (Rogers et al., 1991).

Sample preparation for proteomic analysis. Washed cells (approx. $100 \mathrm{ml}$ ) were thawed and kept at $4{ }^{\circ} \mathrm{C}$ before being lysed by two passes $(60 \mathrm{MPa})$ through an SLM Aminco French Pressure Cell (Thermo Spectronic). Nucleic acids were degraded by incubation on ice $(60 \mathrm{~min})$ following the addition of a solution $(1 \mathrm{ml})$ containing deoxyribonuclease II (2000 units), ribonuclease A (1000 units) and $\mathrm{MgCl}_{2}(50 \mathrm{mM})$. Endogenous proteinase activity was controlled during cell lysis by the addition $(1 \mathrm{ml})$ of a protease inhibitor cocktail. Disrupted cell suspensions were centrifuged $(2000 \mathrm{~g}, 20 \mathrm{~min}$ at $4{ }^{\circ} \mathrm{C}$ ) to remove unbroken cells and the cell-free lysate was then centrifuged again $\left(20000 \mathrm{~g}, 30 \mathrm{~min}\right.$ at $\left.4{ }^{\circ} \mathrm{C}\right)$ to remove the cell envelope (inner and outer membrane). The supernatant was purified further by protein precipitation following addition of 4 vols ice-cold acetone and incubation at $-20^{\circ} \mathrm{C}$ for $2 \mathrm{~h}$. The protein precipitate was collected by centrifugation $\left(10000 \mathrm{~g}, 30 \mathrm{~min}\right.$ at $\left.-5^{\circ} \mathrm{C}\right)$ and residual acetone was removed by evaporation. Purified samples were finally dissolved in rehydration buffer (8 $\mathrm{M}$ electrophoresis-grade urea, $4 \%$ CHAPS, $50 \mathrm{mM}$ DTT $0.2 \%(\mathrm{w} / \mathrm{v})$ ampholytes $\mathrm{pH} 4-7)$ and clarified by centrifugation $\left(20000 \mathrm{~g}, 60 \mathrm{~min}\right.$ at $\left.15^{\circ} \mathrm{C}\right)$. Aliquots of supernatant were then stored at $-80^{\circ} \mathrm{C}$.

Two-dimensional electrophoresis (2D-PAGE). Protein quantification was performed using an RC DC protein assay kit (Bio-Rad) in accordance with the manufacturer's instructions. Isoelectric focusing (IEF) was performed on $17 \mathrm{~cm}$ precast IPG strips with a $\mathrm{pH}$ range of 4-7 using a Protean IEF cell. Briefly, $2 \mathrm{mg}$ cell protein in rehydration buffer was used to passively rehydrate each $17 \mathrm{~cm}$ IPG strip. IEF was run using a linear voltage increase to $10000 \mathrm{~V}$ over $3 \mathrm{~h}$. Focusing occurred for $60000 \mathrm{~V}$ h with a $50 \mu \mathrm{A}$ per strip current limit, and the temperature was maintained at $20^{\circ} \mathrm{C}$. Between three and six replicate IPG strips per sample were run concurrently. After IEF, the IPG strips were subjected to a two-step equilibration as described by Görg \& Weiss (1998). Acrylamide gels (12\% T, 3.3\% C; $0.1 \%$ SDS, $375 \mathrm{mM}$ Tris/ $\mathrm{HCl} \mathrm{pH} 8.8$ ) were cast without a stacking gel in groups of six using a Protean II XL casting chamber. Separation of proteins in the second dimension was done using a Protean II XL Multi cell which allowed six gels to be run simultaneously. Gels were resolved at $30 \mathrm{~mA}$ per gel using a Tris/glycine tank buffer (Laemmli, 1970), which was continually cooled $\left(12{ }^{\circ} \mathrm{C}\right)$, until the dye front reached the bottom of the gel.

Coomassie blue staining. Gels were stained in a solution containing $0.025 \%(\mathrm{w} / \mathrm{v})$ Coomassie blue R-250, $40 \%(\mathrm{v} / \mathrm{v})$ methanol and $7 \%(\mathrm{v} / \mathrm{v})$ acetic acid and destained in a solution containing $50 \%$ $(\mathrm{v} / \mathrm{v})$ methanol $10 \%(\mathrm{v} / \mathrm{v})$ acetic acid.

Image acquisition and analysis. Stained gels were scanned using a GS-800 densitometer operated by the software program PD-Quest.
Image analysis was also done using PD-Quest software and protein spots were detected, matched, manually edited and normalized using total density of all detected spots in the gel. Replicate groups representing each growth $\mathrm{pH}$ in the matchset contained between three and six gels.

Analysis sets containing proteins showing quantitative changes were identified and the spots excised from the gels for MS analysis and protein identification. Differences in the means of protein quantity between replicate groups were analysed for statistical significance using Student's $t$-test.

LC tandem mass spectrometry (LC-MS/MS) and protein identification. The excised 'spots' were washed three times in $50 \mu \mathrm{l}$ ammonium bicarbonate $(100 \mathrm{mM})$ containing $50 \%$ acetonitrile (HPLC grade, Merck) and again in $100 \%$ acetonitrile before drying completely under vacuum. Then $25 \mu \mathrm{l}$ trypsin $(500 \mathrm{ng}$ modified porcine trypsin, $2 \mathrm{mM}$ acetic acid, $80 \mathrm{mM}$ ammonium bicarbonate and $8 \%, v / v$, acetonitrile) was added to rehydrate the spots.

Proteolytic digestion was allowed to occur at $37^{\circ} \mathrm{C}$ for $16 \mathrm{~h}$. Tryptic peptides were reduced by the addition of $1 \mu \mathrm{l} 0.1 \mathrm{M}$ TCEP and the tryptic digestion was stopped by the addition of $25 \mu$ formic acid ( $1 \%$, $\mathrm{v} / \mathrm{v})$. The supernatant was collected and the protein was further extracted in $25 \mu \mathrm{l}$ acetonitrile $(100 \%)$. The combined extracts were reduced in volume to approximately $10 \mu \mathrm{l}$ in a Speed-Vac system (Savant Instruments) before LC-MS/MS analysis.

Peptides were introduced into a Micromass Q-Tof2 mass spectrometer (Waters) through a NanoSpray source coupled to a CapLC system (Waters). Injected samples were desalted on a C18 precolumn $(0.3 \times 3 \mathrm{~mm}, 5 \mu \mathrm{m}$ packing; LC-Packings $)$ before separation on an Atlantis dC18 analytical column $(0.075 \times 50 \mathrm{~mm}, 3 \mu \mathrm{m}$ packing; Waters) using an acetonitrile gradient $(5-70 \%$ containing $0.1 \%$

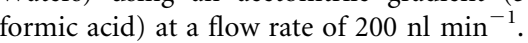

Eluted peptides were ionized through the NanoSpray source with $3 \mathrm{kV}$. A survey scan $(7 \mathrm{~s})$ of the eluting material identified multiple charged species $(+2,+3$ and +4 charge states $)$ and the most abundant $(<4)$ were selected for fragmentation and MS/MS analysis. After signal had been accumulated for each of the fragment ion series for up to $21 \mathrm{~s}$, the system reverted to the survey scan mode to identify further multiply charged species of potential interest.

Following acquisition, MS/MS data were processed and analysed using ProteinLynx 2.0 software (Waters). De novo sequence tags were determined from the fragmentation data and used to search the National Centre for Biotechnology Information (http:// www.ncbi.nlm.nih.gov) non-redundant protein database (May 2005 release) for protein identification matches.

Matched proteins were assessed for quality and validity of the identification. The quality of the identification was correlated to both the number of identified peptides from a protein and the extent of readable sequence from interpretation of the fragmentation pattern. Typically two or more peptides would be required to indicate an identification but, due to the variability in protein sequences between subspecies of F. nucleatum, tentative matches of one or two peptides were manually confirmed through de novo sequencing peptide sequences and BLAST searching of these sequence tags for protein homology. Using this second phase of analysis, we had confidence in protein identity assignments from a single sequenced peptide.

In silico representation of the $\boldsymbol{F}$. nucleatum proteome. A list of 2067 proteins, deduced from the translation of the F. nucleatum genome, was obtained from Integrated Genomics (http://www.integratedgenomics.com/genomereleases.html\#list3). Isoelectric points were calculated using a Microsoft Excel spreadsheet and $\mathrm{p} K_{\mathrm{a}}$ values 
as used by the ExPaSy Compute pI/MW tool (http://au.expasy.org/ tools/pi_tool.html). There were 1800 proteins of predicted molecular mass $10-80 \mathrm{kDa}$, of which $890(\sim 50 \%)$ had a calculated pI between 4 and 7.

\section{RESULTS}

\section{Growth of $F$. nucleatum at high and low pH}

Samples were taken from the chemostat after equilibration over 13 generations so that only proteins displaying a longterm elevation in expression would be resolved. This is in contrast to the many 'stress' proteins that become elevated during abrupt changes in batch growth conditions. Parenthetically, it is worth noting that the organism's $\mu_{\max }$, as determined by measuring cell populations during the exponential growth phase in batch culture (Rogers et al., 1991), maintained at $\mathrm{pH} 7.2$ was estimated to be $0.23 \mathrm{~h}^{-1}$ at $\mathrm{pH}$ 7.2. At the imposed dilution rate of $0.075 \mathrm{~h}^{-1}$, the $\mu_{\text {rel }}$ was therefore 0.3 .

Measurement of nutrient levels in cell-free extracts and cellular protein in culture samples showed that cell number and the utilization of some exogenous nutrients decreased during growth at $\mathrm{pH}$ 6.4. At $\mathrm{pH} 7.2$ and above, energyproducing amino acids (Glu, His, Ser and Lys) and glucose were depleted from the growth medium (data not shown). By comparison, steady state growth at $\mathrm{pH} 6.4$ produced a $10 \%$ and $12 \%$ decrease in glucose and lysine utilization, respectively, and a $35 \%$ decrease in cellular protein $(410 \mathrm{mg}$ protein $\mathrm{ml}^{-1}$ ) when compared with growth at $\mathrm{pH} 7.2$ (630 mg protein $\mathrm{ml}^{-1}$ ). Optimal (cellular) yields were achieved at $\mathrm{pH} 7.4\left(700 \mathrm{mg}\right.$ protein $\left.\mathrm{ml}^{-1}\right)$, while a lower growth yield was observed at $\mathrm{pH} 7.8(610 \mathrm{mg}$ protein $\mathrm{ml}^{-1}$ ).

\section{Protein expression in response to external pH}

Using image analysis software, a total of 17 member gels (the correlation coefficient between each member gel was $>0.7$ ) were used to construct a matchset containing $3,6,4$ and 4 replicate gels derived from growth at $\mathrm{pH} 6.4,7.2,7.4$ and 7.8, respectively. Individual member gels representing each growth $\mathrm{pH}$ are shown in Fig. 1. Protein expression was considered to be altered by growth $\mathrm{pH}$ if the mean spot density from replicate gels was significantly different $(P<0.05)$ from the mean spot density in replicate gels from growth at $\mathrm{pH}$ 7.2. The proteins resolved represent soluble cytoplasmic proteins which have a $\mathrm{pI}$ within the $\mathrm{pH}$ range 4-7 and a molecular mass between about 10 and $80 \mathrm{kDa}$. In silico representation of the F. nucleatum proteome shows two distinct clusters of proteins separated by a region (pI 7.4-7.6) devoid of proteins (Fig. 2). The experimental range used in the present study examines one cluster which contains 890 proteins with a predicted molecular mass of $10-80 \mathrm{kDa}$ and a calculated pI between 4 and 7 .

Using Coomassie blue R250 staining, 116 proteins were chosen for analysis. For expression analysis, density data derived from multiple spots which were identified as isoforms (Fig. 3, spots 20, 21 and 5) were combined to produce a single spot reflecting the total density of all isoforms (Fig. 4). The spots marked 2a and $2 \mathrm{~b}$ were treated as individual spots in determining spot density changes in response to external $\mathrm{pH}$ change. By averaging spot density across each replicate group corresponding to each growth $\mathrm{pH}$, the synthetically derived Gaussian image (Fig. 4) was used to identify proteins displaying significant levels of regulation $(P<0.05)$. Twenty-two proteins were identified as being significantly up- or downregulated in response to high ( $\mathrm{pH} 7.4$ and 7.8) or low external pH (Fig. 3).

\section{Protein identification of regulated proteins}

Following spot excision and in-gel digestion, all differentially expressed proteins provided usable sequence data when analysed by MS/MS (Table 1). Theoretical molecular mass determination corresponded well with observed positions of spots, although measured pIs, in some cases, varied by $0.5 \mathrm{pH}$ units (data not shown). The divergence in the expected pI may be related to the fact that the polymorphum subspecies, used in this study, is not represented in the database, or the protein may have undergone some form of charge-modifying post-translational modification (Campostrini et al., 2005). Comparison of the predicted pI of proteins from the two subspecies represented in the database indicates a degree of heterogeneity. For example, the theoretical pI of proteins such as adenylosuccinate synthetase (spot 7) in the nucleatum and vincentii database was 5.50 and 5.95 respectively.

Proteins were identified on the basis that several observed peptide sequences matched those found in the F. nucleatum (subspecies nucleatum or vincentii) protein database (NCBI). One hypothetical protein (spot 18) was identified on the basis of a single peptide containing 19 amino acids which represented approximately $17 \%$ of the protein's theoretical molecular mass of $11184 \mathrm{Da}$. Due to the substantial size of the peptide, we feel, with some confidence, that a presumptive assignment of the protein could be made. Protein identification and the degree of regulation of each identified protein are shown in Table 1.

Protein spot 7 (Figs 3 and 4) proved to be the only protein for which a confident single assignment could not be provided. Genomic information based on the subspecies vincentii genome suggested the two proteins identified as adenylosuccinate synthase (34762528) and NAD-specific glutamate dehydrogenase (34764006), which have a molecular mass/pI of $47.3 \mathrm{kDa} / 5.95$ and $46.5 \mathrm{kDa} / 6.5$, respectively. It is unclear, therefore, why the spot contained a mixture of both proteins but, as discussed earlier, this may reflect the divergence in pIs seen for certain proteins in the databases used and/or the migration of proteins in SDSPAGE, which can be sequence-dependent (Campostrini et al., 2005). MS/MS analysis of individual spots which differed slightly in pI (spots 2a, 2b, 5, 20 and 21: Fig. 3) showed that they contained the same protein (data not 

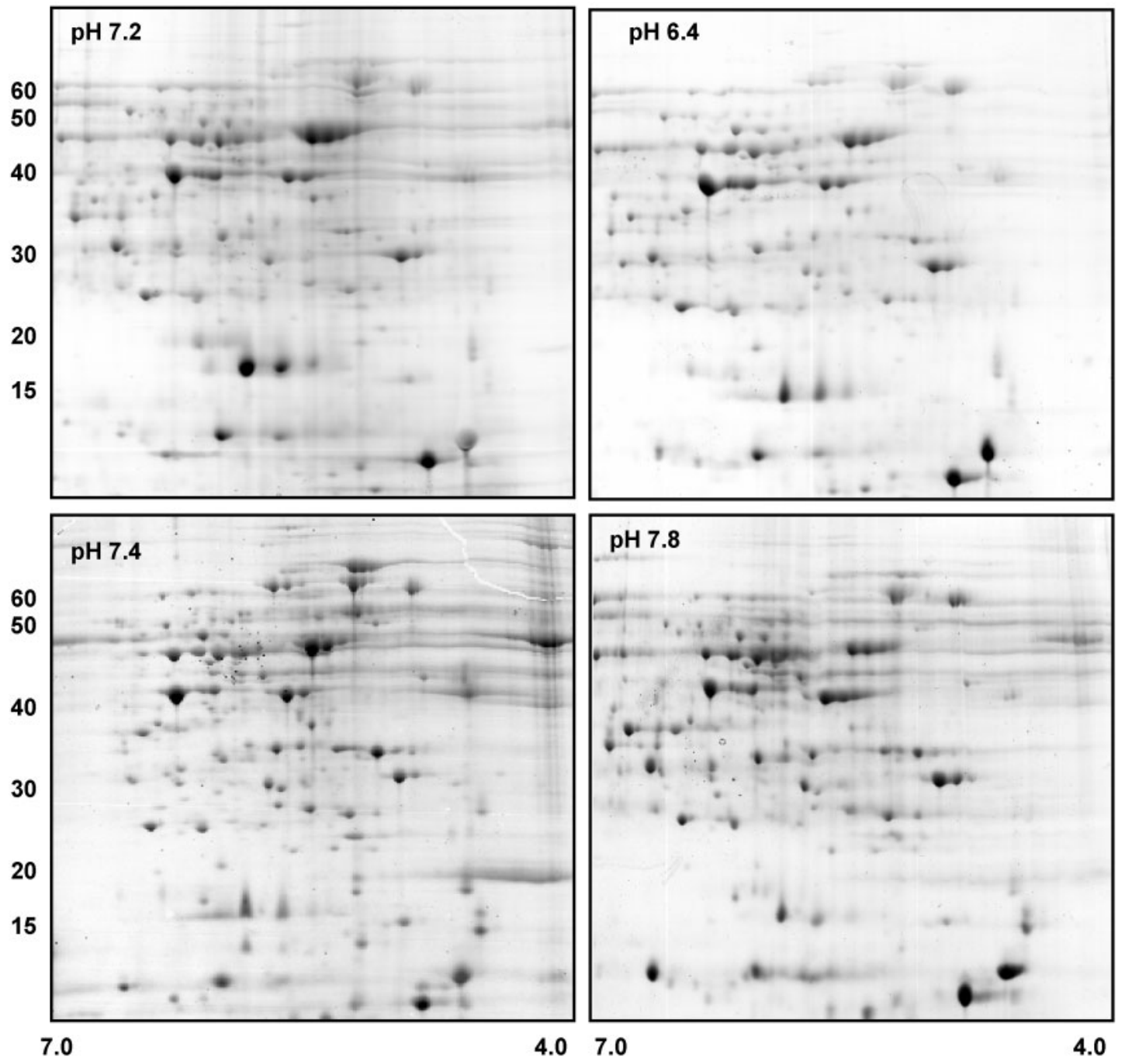

Fig. 1. Proteins expressed by F. nucleatum grown by continuous culture in a chemostat, separated by 2D-PAGE and stained with Coomassie blue R250. Representative gels are shown from each replicate group, labelled with the culture pH. The horizontal axes represent the iso-electric focusing gradient and the vertical axes represent molecular mass (kDa).

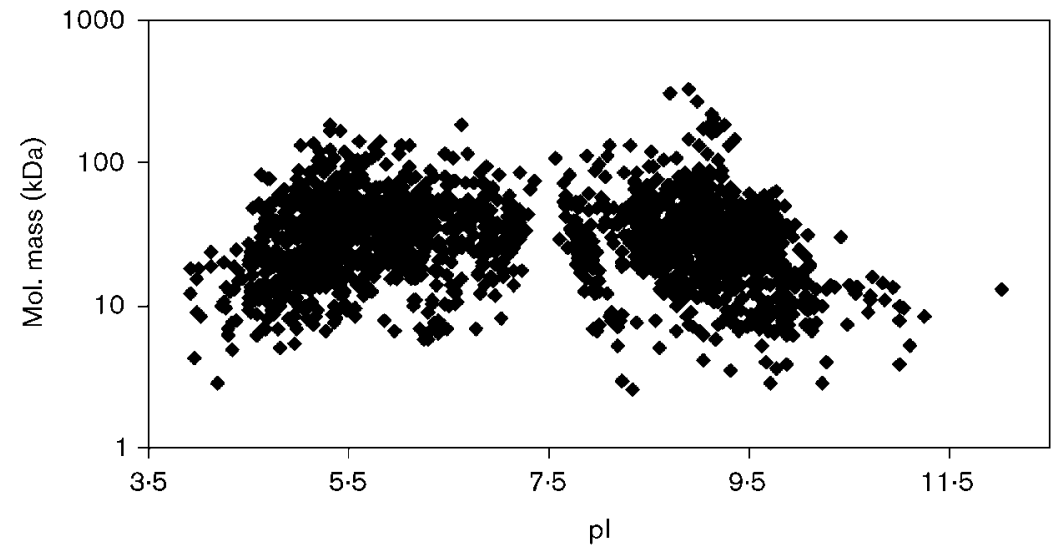

Fig. 2. In silico representation of the entire proteome of F. nucleatum (ATCC 25586) separated by 2D-PAGE. 

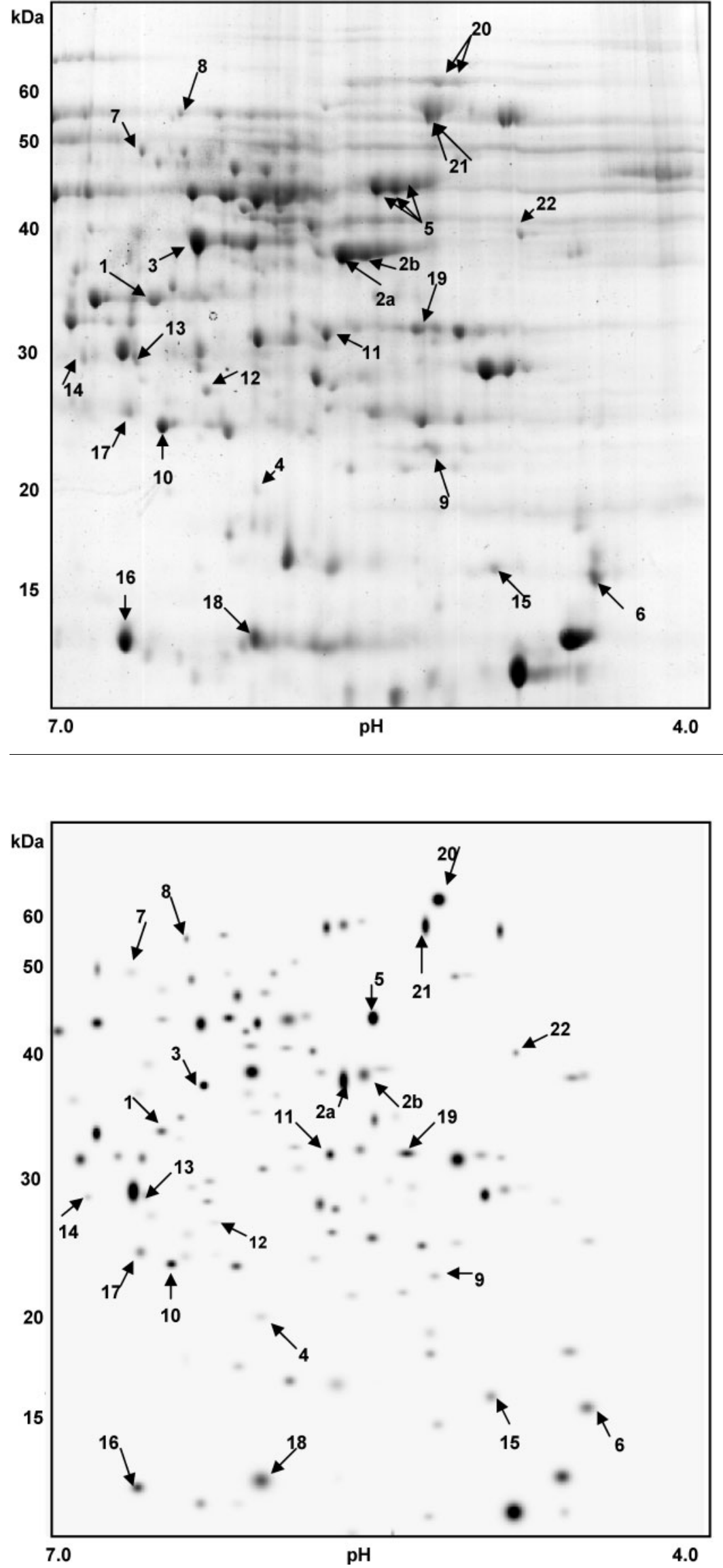

Fig. 3. Proteins expressed by $F$. nucleatum grown by continuous culture in a chemostat, separated by 2D-PAGE and stained with Coomassie blue R250. Numbered spots represent proteins which were regulated by culture $\mathrm{pH}$; spots $2 \mathrm{a}, 2 \mathrm{~b}, 5,20$ and 21 represent distinct isoforms.
Fig. 4. Gaussian image of 2D-PAGE of proteins expressed by $F$. nucleatum grown by continuous culture in a chemostat. Expression analysis based on this image was used to identify proteins (numbered spots) regulated by culture $\mathrm{pH}$. Spot density values from spots 5,20 and 21, which represented distinct isoforms (Fig. 3) were combined to produce a single spot. Isoforms represented by spots $2 \mathrm{a}$ and $2 \mathrm{~b}$ were not combined, to determine potential regulation of each isoform. 
Table 1. Cytoplasmic proteins from F. nucleatum up- or downregulated following growth at $\mathrm{pH} 6.4,7.4$ or 7.8 relative to $\mathrm{pH} 7.2$

\begin{tabular}{|c|c|c|c|c|c|c|c|c|}
\hline \multirow[t]{2}{*}{ Function } & \multirow[t]{2}{*}{ Spot $^{\star}$} & \multirow[t]{2}{*}{ Protein name $\dagger$} & \multirow{2}{*}{$\begin{array}{c}\text { NCBI accession } \\
\text { no. } \ddagger\end{array}$} & \multirow{2}{*}{$\begin{array}{c}\text { Subspecies } \\
\text { matched } \S\end{array}$} & \multirow{2}{*}{$\begin{array}{l}\text { MS/MS sequenced } \\
\text { peptides matched } \|\end{array}$} & \multicolumn{3}{|c|}{ Mean spot quantity ratio 9} \\
\hline & & & & & & pH 6.4/7.2 & pH 7.4/7.2 & pH 7.8/7.2 \\
\hline \multirow[t]{3}{*}{ Glycolysis } & 1 & Fructose-bisphosphate aldolase & 19713785 & nucleatum & 8 & 1.7 & 5.7 & 6.4 \\
\hline & 5 & Enolase & 19713005 & nucleatum & 3 & 0.9 & 0.7 & $0.8 \#$ \\
\hline & 8 & Pyruvate kinase & 19713006 & nucleatum & 6 & 0.9 & 0.6 & $0.5 \#$ \\
\hline \multicolumn{9}{|l|}{ Amino acid synthesis } \\
\hline Tryptophan synthesis & 14 & Anthranilate synthase & $\begin{array}{l}34762843 \\
19713994\end{array}$ & $\begin{array}{c}\text { vincentii } \\
\text { nucleatum }\end{array}$ & 3 & 4.1 & 1.1 & 0.9 \\
\hline \multicolumn{9}{|l|}{ Amino acid catabolism } \\
\hline $\begin{array}{l}\text { Histidine catabolism } \\
\text { Cellular energy }\end{array}$ & \multicolumn{7}{|c|}{ Cellular energy } & 0.8 \\
\hline Redox group electron acceptor & 6 & Flavodoxin & 19714004 & nucleatum & 2 & 1.6 & 84.5 & 71 \\
\hline 2-Oxoglutarate pathway & 7 & NAD-specific glutamate dehydrogenase & 34764006 & vincentii & 4 & 4.3 & 1.4 & 2.9\# \\
\hline Butyrate synthesis & 10 & Acetoacetate-butyrate CoA transferase & 19713099 & nucleatum & 5 & 1.9 & 0.8 & 1.0 \\
\hline $\begin{array}{l}\text { Butanoate metabolism } \\
\text { Anabolic processes }\end{array}$ & \multicolumn{7}{|c|}{ Anabolic processes } & 0.8 \\
\hline Folate biosynthesis & 4 & $\begin{array}{l}\text { Oxygen-insensitive NADPH nitroreductase } \\
\text { dihydropteridine reductase }\end{array}$ & 34764235 & vincentii & 2 & 14.0 & 6.2 & 1.3 \\
\hline De novo nucleotide synthesis & 7 & Adenylosuccinate synthetase & 34762528 & vincentii & 5 & 4.3 & 1.4 & 2.9\# \\
\hline One-carbon units to folate pool & 9 & Formiminotetrahyrofolate cyclodeaminase & $\begin{array}{l}19714274 \\
34764298\end{array}$ & $\begin{array}{l}\text { nucleatum } \\
\text { vincentii }\end{array}$ & 6 & 0.9 & 12.6 & 16.4 \\
\hline Fatty acid synthesis & 11 & Malonyl-CoA acyl carrier protein transacylase & 19713580 & nucleatum & 3 & 4.0 & 10.0 & 11.4 \\
\hline AMP recycling & 12 & Adenylate kinase & $\begin{array}{l}19714935 \\
34763306\end{array}$ & $\begin{array}{l}\text { nucleatum } \\
\text { vincentii }\end{array}$ & 2 & 7.8 & 7.1 & 29.3 \\
\hline \multirow[t]{4}{*}{ Protein translation } & $2 \mathrm{a}$ & Elongation factor Ts (DnaK) & 60416365 & nucleatum & 13 & 1.4 & 1.4 & 2.1 \\
\hline & $2 \mathrm{~b}$ & Elongation factor Ts & 60416365 & nucleatum & 15 & 1.1 & 0.7 & $1.5 \#$ \\
\hline & 20 & $70 \mathrm{kDa}$ chaperonin (DnaK) & 19713544 & nucleatum & 3 & 1.1 & 14.4 & 2.7 \\
\hline & 21 & $60 \mathrm{kDa}$ chaperonin (GroEL) & 19714198 & nucleatum & 6 & $0.6 \#$ & 1.9 & $1.6 \#$ \\
\hline \multirow[t]{2}{*}{ Cell division } & 19 & Peptidyl-prolyl cis-trans isomerase & 19713714 & nucleatum & 3 & 0.2 & 1.1 & 1.2 \\
\hline & 22 & FtsZ cell division protein & $\begin{array}{l}19715120 \\
34763161\end{array}$ & $\begin{array}{l}\text { nucleatum } \\
\text { vincentii }\end{array}$ & 5 & 0.9 & 2.5 & 1.9 \\
\hline \multirow[t]{4}{*}{ Unknown } & 15 & Hypothetical cytosolic & 34762615 & vincentii & 6 & 0.1 & 5.6 & 2.7 \\
\hline & 16 & Hypothetical cytosolic & 19714743 & nucleatum & 2 & 3.7 & $5.8 \#$ & 18.3 \\
\hline & 17 & Hypothetical cytosolic & 19713650 & nucleatum & 7 & 3.5 & 1.5 & 2.1 \\
\hline & 18 & Hypothetical protein & 34763495 & vincentii & 1 & 1.1 & $0.6 \#$ & 0.5 \\
\hline
\end{tabular}

${ }^{\star}$ Numbers refer to the proteins labelled in Figs 3 and 4.

$\dagger$ Putative functions were assigned on the basis of the presence of homologues in the database for F. nucleatum.

$\ddagger$ National Centre for Biotechnology Information.

\$Protein matched to the subspecies represented in the database for F. nucleatum.

\|Number of sequenced peptides from MS/MS analysis found to match the identified protein.

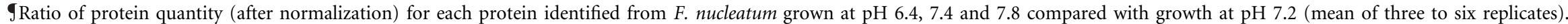

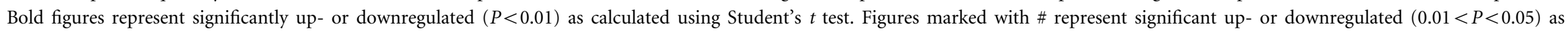
calculated using Student's $t$-test. 
shown). The differences between the isoforms may be due to post-translational processing of the protein.

Eight proteins were upregulated in response to a shift to acid or basic conditions from $\mathrm{pH}$ 7.2. Of these, five (spots, 1, 6, 11,12 and 16) showed higher levels of upregulation at elevated $\mathrm{pH}$ compared with growth at $\mathrm{pH}$ 6.4. In contrast, spots 17,7 and 4 were upregulated to a greater degree at the acidic $\mathrm{pH}$. No proteins appeared to be downregulated under both acidic and alkaline conditions.

Four proteins (spots, 9, 20, 22, 2a, 2b) were upregulated only in response to high $\mathrm{pH}$. Notably, these included the DnaK homologue, heat-shock protein (Hsp) 70 (spot 20). Two isoforms of elongation factor Ts (EF-Ts) were also identified in this group (spots $2 \mathrm{a}$ and $2 \mathrm{~b}$ ), both being upregulated at $\mathrm{pH}$ 7.8. The only metabolic enzyme found in this group was formiminotetrahydrofolate cyclodeaminase (spot 9).

Repression of the glycolytic pathway may also occur during a shift to high external $\mathrm{pH}$, as enolase (spot 5) and the allosterically controlled pyruvate kinase (spot 8 ) were both significantly downregulated at high $\mathrm{pH}$. One of four highly regulated hypothetical proteins (spot 18) was also significantly downregulated at $\mathrm{pH}$ 6.4.

Two proteins were upregulated only in response to acidic $\mathrm{pH}$ (spots 10 and 14) and one protein (spot 19) was downregulated only at $\mathrm{pH} 6.4$.

The enzymes associated with glutamic acid catabolism (spots 13 and 3) showed a similar upregulation in response to growth $\mathrm{pH}$. An external $\mathrm{pH}$ of 6.4 produced a 1.6- and 2fold increase in expression for glutaconate-CoA transferase subunit B (spot 13) and glutamate forminotransferase (spot 3 ), respectively. However, at an external $\mathrm{pH}$ above 7.2, both enzymes were significantly downregulated (1.7-fold for spot 3 and 1.4-fold for spot 13) at $\mathrm{pH} 7.4$.

\section{DISCUSSION}

F. nucleatum is well recognized as an important organism during the development of the plaque biofilm. Its abilities to bind to other plaque inhabitants and host epithelial cells (Kolenbrander \& London, 1993; Shaniztki et al., 1997; Han et al., 2000; Edwards et al., 2006) and to create hypoxic environments (Diaz et al., 2002) have been well documented. In addition, its isolation from both supra- and subgingival plaque reflects its ability to grow over a relatively wide $\mathrm{pH}$ range compared with other pathogenic inhabitants of plaque. In the present study we have examined the expression of a subset of cytoplasmic $\mathrm{pH}$-dependent proteins with a $\mathrm{pI}$ range between 4 and 7. Determination of the expression of other $\mathrm{pH}$-dependent cytoplasmic proteins ( $\mathrm{pI}$ range 7.5-10) and proteins associated with the cell envelope are currently under investigation.

We are aware that poor design of proteomic experiments can lead to false or inconclusive data (Wilkins et al., 2006).
In dealing with these issues, we incorporated replicate gels $(n=3-6)$ and replicate harvesting of cells during prolonged exposure to the imposed changes in extracellular $\mathrm{pH}$. It is also important to note that protein expression can be strain specific and that protein expression by the organism when grown as a biofilm was not part of the present study.

We also chose to study a subset of the proteome by examining a relatively narrow ( $\mathrm{pH} 4-7$ ) isoelectric focusing range. The use of a wider $\mathrm{pH}$ range $(\mathrm{pH} 3-10)$ has the potential to cover a greater proportion of the proteome, but recent studies (Campostrini et al., 2005) have highlighted the fact that such a range can lead to poor resolution and produce single spots containing $2-5$ proteins. The protocol used in this study supported this view, as only one spot out of 22 was identified as containing a mixture of two proteins. It also enabled the identification of spot boundaries to be optimized so that accurate spot excision could be done on representative gels.

Even allowing for the relatively high number of replicate gels required to produce statistically significant data, the biological significance and accuracy of determining relatively small changes (less than twofold) in protein expression may be questionable. However, initial examination of the largest changes in protein expression observed during changes in growth $\mathrm{pH}$ may help establish a clear biological story.

\section{Proteins regulated by acidic $\mathrm{pH}$}

In dealing with this, growth under acidic conditions led to the regulation (more than fourfold) of several proteins associated with energy synthesis and cell division. Reduced cell numbers were obtained at a growth $\mathrm{pH}$ of 6.4, and this is reflected in the fivefold downregulation of peptidylprolyl cis-trans isomerase. Peptidyl-prolyl cis-trans isomerase accelerates protein folding by catalysing the cistrans isomerization of proline imide bonds, and low expression of this enzyme in eukaryotic cells leads to mitotic arrest.

In contrast, the upregulation of the enzymes associated with glutamate fermentation via the 2-oxoglutarate pathway (NADP-specific glutamate dehydrogenase, acetoacetatebutyrate CoA transferase and glutaconate-CoA transferase subunit B) suggests that the organism has an increased capacity to utilize exogenous glutamate and that produced by the metabolism of histidine. Wilkins et al. (2001) reported that following acidification, NADP-specific glutamate dehydrogenase was upregulated sixfold in Streptococcus oralis. The potential upregulation of the 2oxoglutarate pathway at $\mathrm{pH} 6.4$ indicates an increased requirement for ATP, which is in contrast to the decrease in the cell numbers and supports the view that energyrequiring protective mechanisms are used by the organism to maintain internal homeostasis. Due to their similarities in molecular mass and pI, spot 7 was identified as containing both NADP-specific glutamate dehydrogenase 
and adenylosuccinate synthase proteins. Both enzymes are associated with the synthesis of ATP, and upregulation of either reflects increased energy production. Further evidence confirming the increase of glutamate metabolism at acidic $\mathrm{pH}$ is provided by the upregulation of glutamate formiminotransferase, an enzyme that converts histidine to glutamate by donating a formimino group to the one carbon pool (tetrahydrofolate). Glutamate can then be catabolized via the 2-oxoglutarate pathway leading to the synthesis of ATP.

The fourfold upregulation of anthranilate synthase at pH 6.4 also adds weight to the overall increase in ATP synthesis at $\mathrm{pH}$ 6.4. This enzyme catalyses the formation of anthranilate from glutamine and chorismate, the latter being a key intermediate in the synthesis of aromatic amino acids. The absence of genes needed to complete the synthetic pathways, however (Kapatral et al., 2003), indicates that the organism cannot synthesize tryptophan, tyrosine or phenylalanine. The other by-products of the reaction catalysed by anthranilate synthase include pyruvate and glutamate, suggesting that its upregulation may be an additional means of deriving energy from glucose and glutamine fermentation. Glutamate conversion to glutamine may occur in the periodontal pocket as a result of increased ammonia production caused by the presence of asaccharolytic bacteria (Hyatt \& Hayes, 1975).

The flavin-mononucleotide-dependent enzyme $\mathrm{O}_{2}$-insensitive NADPH nitroreductase dihydropteridine reductase, involved in co-factor biosynthesis, was also significantly upregulated at $\mathrm{pH}$ 6.4; although its function in assisting growth remains unclear, it should be noted that it was also upregulated (3.2-fold) in $S$. oralis following growth at pH 5.5 (Wilkins et al., 2001).

\section{Proteins regulated by alkaline pH}

In contrast to the results at acidic $\mathrm{pH}$, growth under alkaline conditions produced the largest changes in proteins associated with the glycolytic pathway and iron limitation. F. nucleatum has been reported to utilize glucose, fructose and galactose as potential energy sources (Robrish et al., 1987). In this context, fructose-bisphosphate aldolase was upregulated about sixfold under alkaline conditions while the expression of other glycolytic enzymes, enolase and the allosterically controlled pyruvate kinase were downregulated to a lesser degree. It has been reported that in resting (non-growing) cells the fermentation of glutamate and lysine occurs preferentially and the energy produced is used for the active transport of glucose, which is stored as intracellular polysaccharide (IP) (Robrish et al., 1987; Robrish \& Thompson, 1990). Our earlier studies on $F$. nucleatum growing in continuous culture showed that during glutamate fermentation, growth at $\mathrm{pH} 7.8$ produced maximum levels of IP (Zilm et al., 2003). It has been reported that high levels of glutamate are present in the inflamed periodontium (Singer \& Kleinberg, 1983), and fructose diphosphate has been previously described as a branch point in determining the fate of glucose into energy (ATP) or synthesis of IP (Robrish \& Thompson, 1990). Metabolically, the downregulation of enolase and pyruvate kinase would lead to the build-up of glycolytic intermediates that would be channelled back to fructose diphosphate by the upregulation of fructose-bisphosphate aldolase activity, a freely reversible reaction. The build-up of fructose 1,6-diphosphate and the continued fermentation of glutamate would promote polymer synthesis as proposed by Robrish \& Thompson (1990). The reduction in acidic end products caused by the synthesis of IP and the concomitant ammonia production (glutamate fermentation) may assist the increased $\mathrm{pH}$ observed in the diseased gingival sulcus.

The observed upregulation ( $>12$-fold) of formiminotetrahydrofolate cyclodeaminase would also contribute to, and maintain, a rise in the periodontal pocket $\mathrm{pH}$. Catabolism of glutamate via the 2-oxoglutarate pathway produces a formimino group which is transferred to 5,10-methyltetrahydrofolate by formiminotetrahydrofolate cyclodeaminase, as in the eukaryote pathway (Kapatral et al., 2002), leading to the synthesis of ATP and ammonia.

The fermentation of glucose and serine by F. nucleatum produces pyruvate which can be converted to oxaloacetate by phosphoenolpyruvate carboxykinase and to acetyl-CoA by pyruvate flavodoxin oxidoreductase (Kapatral et al., 2002). The expression of flavodoxin was greatly upregulated at pH 7.4 and 7.8 (84- and 71-fold, respectively). Flavodoxin has a very low redox potential and acts in a manner similar to ferredoxin but differs in that flavin mononucleotide acts as a redox group instead of iron and sulphur. Flavodoxin is usually found to be upregulated in anaerobes in response to iron limitation (Kapatral et al., 2002). Although iron $\left(\mathrm{FeSO}_{4} \cdot 7 \mathrm{H}_{2} \mathrm{O}\right)$ was added to the growth medium, whether the culture was iron limited was unclear. The availability of haemin and non-haemin iron sources such as ferric, ferrous and nitrogenous inorganic iron, along with transferrin and lactoferrin, is an important factor in the microbial ecology of the gingival sulcus/periodontal pocket and is influenced by the flow rate of gingival crevicular fluid, and the degree of bleeding. F. nucleatum is known to possess $\mathrm{ABC}$ transporters for uptake of chelated iron and ferric iron (Kapatral et al., 2002). Gene regulation, and the expression of virulence factors, by Porphyromonas gingivalis is thought to be controlled by the ferric uptake regulatory protein (Fur), which acts as a transcriptional repressor during iron-rich environmental conditions (Genco, 1995). The expression, by F. nucleatum, of $\mathrm{pH}$-dependent noniron redox acceptors such as flavodoxin may be important for continued metabolism during iron-limiting/high-pH conditions experienced in the inflamed gingival sulcus/ pocket.

The expression of the constitutively produced heat-shock chaperonins GroEL and DnaK appeared also to be upregulated under alkaline growth conditions. Under the steady-state conditions used in this study, the role of 
chaperonins is to modulate the folding of nascent polypeptides following translation as opposed to repairing or destroying denatured proteins during abrupt changes in growth conditions that induce a cellular stress response (Goulhen et al., 2003). The increased expression of GroELlike proteins, under conditions which mimic those in the periodontal pocket, is important as they have been reported to be immunodominant bacterial antigens that may play a role in pathogenesis by stimulating the host immune response (Skår et al., 2003).

\section{Proteins regulated by both acidic and alkaline pH}

A third category of proteins identified were those that showed altered expression (more than fourfold) in response to both alkaline and acidic conditions. The upregulation of adenylate kinase is not surprising since amino acid fermentation pathways were also upregulated. This enzyme is essential for ADP/AMP recycling in energetically active cells.

One of the many reported responses in Streptococcus mutans to the acid stress is to increase the proportion of monounsaturated fatty acids in the cell membrane by isomerizing trans unsaturated bonds in the hydrocarbon chains to their cis isomers (Fozo \& Quivey, 2004). The conversion of fatty acids is catalysed by FabM protein (trans-2,cis-3-decenoylACP isomerase) and database searches indicate that FabM homologues exist only in streptococcal and staphylococcal species and F. nucleatum (Fozo \& Quivey, 2004). Growth of $F$. nucleatum at $\mathrm{pH} 6.4,7.4$ and 7.8 produced an upregulation (4-, 10- and 11-fold, respectively) of malonylCoA-acyl carrier protein transacylase, which is one of six enzymes essential for fatty acid synthesis in bacteria. Whether the increase in fatty acid synthesis is associated with a change in unsaturated fatty acid composition by FabM protein is unclear.

\section{Hypothetical proteins}

Four proteins $(34762615,19714743,19713650,34763495)$ whose expression was regulated in response to growth $\mathrm{pH}$ were represented in the $F$. nucleatum genome but were identified as having no known function. With the exception of spot 17 (19713650) all of the hypothetical proteins had a molecular mass below $20 \mathrm{kDa}$, and their expression may play a role in the organism's response to $\mathrm{pH}$. The potential function and identification of these proteins will form the basis for future studies.

\section{Protein isoforms}

Several proteins (such as EF-Ts, enolase), including the chaperonins GroEL and DnaK, were expressed as isoforms (Fig. 3); this has also been reported (Wilkins et al., 2002) following culture of $S$. mutans at low $\mathrm{pH}$. It was also reported that the relative amounts and number of isoforms were influenced by growth conditions. The expression of isoforms identified as EF-Ts (Fig. 3, spots $2 \mathrm{a}$ and $2 \mathrm{~b}$ ) was examined and no significant change was seen over the growth $\mathrm{pH}$ range used in the present study. In all cases, the isoforms seen were probably the result of charge-altering post-translational modifications, such as deamidation or phosphorylation. The peptides from the tryptic digests of the observed isoforms of GroEL were investigated using the ExPaSy 'FindMod' tool (http://us.expasy.org/tools/findmod) and while no highly probable modifications were identified, GroEL is known to be phosphorylated in E. coli (Sherman \& Goldberg, 1992).

\section{Conclusion}

The determination of genome sequences for oral pathogens has recently allowed researchers to compare the effect of environmental changes on an organism's proteome and relate them to the vast amount of published physiological data. To our knowledge, the present study represents the first empirical proteomic investigation of the genus Fusobacterium. The Fusobacterium proteome was found to be dynamic, varying according to environmental $\mathrm{pH}$ under conditions of constant growth rate. F. nucleatum responded to growth at low (suboptimal) $\mathrm{pH}$ by upregulating the expression of proteins associated with catabolism of glutamate for the generation of ATP and ammonia, the latter contributing to the alkalinization of the gingival sulcus. Conversely, under neutral to alkaline $\mathrm{pH}$ conditions, the increased utilization of glucose was associated with upregulation of enzymes involved in energy storage. Our results provide a molecular basis for the alterations in metabolism previously described and have identified several proteins associated with iron limitation and fatty acid synthesis, which might not otherwise have been identified as part of the $\mathrm{pH}$-dependent response. Studies on adhesins (Kolenbrander \& London, 1993) and oxygen metabolism (Diaz et al., 2002) have clearly identified F. nucleatum as an important organism in the adaptation of pathogenic bacteria in the gingival sulcus. In this study we have demonstrated that a number of proteins are regulated in $F$. nucleatum as part of a coordinated response to environmental $\mathrm{pH}$, and that the response leads to changes in the environment that are conducive to the establishment and growth of a new climax community associated with periodontal diseases.

\section{ACKNOWLEDGEMENTS}

This work was supported by The Australian Dental Research Foundation.

\section{REFERENCES}

Bickel, M. \& Cimasoni, G. (1985). The pH of human crevicular fluid measured by a new microanalytical technique. J Periodont Res 20, 35-40.

Brook, I. (2002). Cutaneous and subcutaneous infections in newborns due to anaerobic bacteria. J Perinat Med 30, 197-208. 
Campostrini, N., Areces, L. B., Rappsilber, J., Pietrogrande, M. C., Dondi, F., Pastorino, F., Ponzoni, M. \& Righetti, G. (2005). Spot overlapping in two-dimensional maps: a serious problem ignored for much too long. Proteomics 5, 2385-2395.

Diaz, P. I., Zilm, P. S. \& Rogers, A. H. (2002). Fusobacterium nucleatum supports the growth of Porphyromonas gingivalis in oxygenated and carbon dioxide-depleted environments. Microbiology 148, 467-472.

Dzink, J. L., Sheenan, M. T. \& Socransky, S. S. (1990). Proposal of three subspecies of Fusobacterium nucleatum Knorr 1922: Fusobacterium nucleatum subsp. nucleatum subsp. nov., comb. nov.; Fusobacterium nucleatum subsp. polymorphum subsp. nov., nom. rev., comb. nov.; and Fusobacterium nucleatum subsp. vincentii subsp. nov., nom. rev., comb. nov. Int J Syst Bacteriol 40, 74-78.

Edwards, M., Grossman, T. J. \& Rudney, J. D. (2006). Fusobacterium nucleatum transports non-invasive Streptococcus cristatus into human epithelial cells. Infect Immun 74, 654-662.

Fozo, E. M. \& Quivey, R. G., Jr (2004). The fabM gene product of Streptococcus mutans is responsible for the synthesis of monounsaturated fatty acids and is necessary for survival at low $\mathrm{pH}$. J Bacteriol 186, 4152-4158.

Genco, C. A. (1995). Regulation of hemin and iron transport in Porphyromonas gingivalis. Adv Dent Res 9, 41-47.

Goulhen, F., Greiner, D. \& Mayrand, D. (2003). Oral microbial heatshock proteins and their potential contributions to infections. Crit Rev Oral Biol Med 14, 399-412.

Görg, A. \& Weiss, W. (1998). In Cell Biology. A Laboratory Handbook, vol. 4, 2nd edn, pp. 386-297. Edited by J. E. Celis. New York: Academic Press.

Haffajee, A. D. \& Socransky, S. S. (1994). Microbial etiological agents of destructive periodontal diseases. Periodontol 2000 5, 78-111.

Haffajee, A. D. \& Socransky, S. S. (2005). Microbiology of periodontal diseases: introduction. Periodontol 2000 38, 9-12.

Haffajee, A. D. \& Socransky, S. S. (2006). Introduction to microbial aspects of periodontal biofilm communities, development and treatment. Periodontol 2000 42, 7-12.

Hamilton, I. R., Phipps, P. J. \& Ellwood, D. C. (1979). Effect of growth rate and glucose concentration on the biochemical properties of Streptococcus mutans Ingbritt in continuous culture. Infect Immun 26, 861-869.

Han, Y. W., Shi, W., Huang, G. T., Kinder Haake, S., Park, N. H., Kuramitsu, H. \& Genco, R. J. (2000). Interactions between periodontal bacteria and human oral epithelial cells: Fusobacterium nucleatum adheres to and invades epithelial cells. Infect Immun 68, 3140-3146.

van der Hoeven, J. S., de Jong, M. H., Camp, P. J. M. \& van der Kieboom, C. W. A. (1985). Competition between oral Streptococcus species in the chemostat under alternating conditions of glucose limitation and excess. FEMS Microbiol Ecol 31, 373-379.

Holt, S. C. \& Ebersole, J. L. (2005). Porphyromonas gingivalis, Treponema denticola and Tannerella forsythia: the 'red complex', a prototype polybacterial pathogenic consortium in periodontitis. Periodontol 2000 38, 75-122.

Hoskinsson, P. A. \& Hobbs, G. (2005). Continuous culture - making a comeback? Microbiology 151, 3153-3159.

Hyatt, A. T. \& Hayes, M. L. (1975). Free amino acids and amines in human dental plaque. Arch Oral Biol 20, 203-209.

Kapatral, V., Anderson, I., Ivanova, N. \& 23 other authors (2002). Genome sequence and analysis of the oral bacterium Fusobacterium nucleatum strain 25586. J Bacteriol 184, 2005-2018.
Kapatral, V., Ivanova, N., Anderson, I. \& 11 other authors (2003). Genome analysis of $F$. nucleatum subsp. vincentii and its comparison with the genome of F. nucleatum ATCC 25586. Genome Res 13, $1180-1189$.

Kolenbrander, P. E. \& London, J. (1993). Adhere today, here tomorrow: oral bacteria adherence. J Bacteriol 175, 3247-3252.

Kung, R. T. V., Ochs, B. \& Goodson, M. (1990). Temperature as a periodontal diagnostic. J Clin Periodontal 17, 557-563.

Laemmli, U. K. (1970). Cleavage of structural proteins during the assembly of the head of bacteriophage T4. Nature 227, 680-685.

Marsh, P. D. (1991). Sugar, fluoride, $\mathrm{pH}$ and microbial homeostasis in dental plaque. Proc Finn Dent Soc 87, 515-525.

Marsh, P. D. (1994). Microbial ecology of dental plaque and its significance in health and disease. Adv Dent Res 8, 263-271.

Mikasaki, K. (2006). Periodontics Information Centre. Periodontal Immunology [Online: http://www.dent.ucla.edu/pic/members/ immunology/immunology2.html]. Accessed 6 February, 2006.

Robrish, S. A. \& Thompson, J. (1990). Regulation of fructose metabolism and polymer synthesis by Fusobacterium nucleatum ATCC10953. J Bacteriol 172, 5714-5723.

Robrish, S. A., Oliver, C. \& Thompson, J. (1987). Amino aciddependent transport of sugars by Fusobacterium nucleatum ATCC 10953. J Bacteriol 169, 3891-3897.

Rogers, A. H., Zilm, P. S., Gully, N. J., Pfennig, A. L. \& Marsh, P. D. (1991). Aspects of the growth and metabolism of Fusobacterium nucleatum ATCC 10953 in continuous culture. Oral Microbiol Immunol 6, 250-255.

Shaniztki, B., Hurwitz, D., Smorodinsky, N., Ganaeshkumar, N. \& Weiss, E. I. (1997). The identification of a Fusobacterium nucleatum PK1594 galactose binding adhesion which mediates coaggregation with periodontopathic bacteria and hemagglutination. Infect Immun 65, 5231-5237.

Sherman, M. Yu. \& Goldberg, A. L. (1992). Heat shock in Escherichia coli alters the protein-binding properties of the chaperonin GroEL by inducing its phosphorylation. Nature 357, 167-169.

Singer, D. L. \& Kleinberg, I. (1983). The free amino acids inhuman dental plaque. Arch Oral Biol 28, 873-878.

Skår, C. K., Kruger, P. G. \& Bakken, V. (2003). Characterisation and subcellular localization of the GroEL-like and DnaK-like proteins isolated from Fusobacterium nucleatum ATCC 10953. Anaerobe 9, 305-312.

Slots, J. (2005). Herpesviruses in periodontal diseases. Periodontol 2000 38, 33-62.

Socransky, S. S. \& Haffajee, A. D. (2005). Periodontal microbial ecology. Periodontol 2000 38, 135-187.

Socransky, S. S., Manganielli, A. D., Propas, D., Orum, U. \& van Houte, J. (1977). Bacteriological studies of developing supragingival dental plaque. J Periodont Res 12, 90-106.

Socransky, S. S., Haffajee, A. D., Cugini, M. A., Smith, C. \& Kent, R. L., Jr (1998). Microbial complexes in subgingival plaque. J Clin Periodontol 25, 134-144.

Takahashi, N. (2003). Acid-neutralizing activity during amino acid fermentation by Porphyromonas gingivalis, Prevotella intermedia and Fusobacterium nucleatum. Oral Microbiol Immunol 18, 109-113.

Takahashi, N. (2005). Microbial ecosystem in the oral cavity: metabolic diversity in an ecological niche and its relationship with oral diseases. Int Congr Ser 1284, 103-112. 
Wilkins, J. C., Homer, K. A. \& Beighton, D. (2001). Altered protein expression of Streptococcus oralis cultured at low $\mathrm{pH}$ revealed by two-dimensional gel electrophoresis. Appl Environ Microbiol 67, 3396-3405.

Wilkins, J. C., Homer, K. A. \& Beighton, D. (2002). Analysis of Streptococcus mutans proteins modulated by culture under acidic conditions. Appl Environ Microbiol 68, 2382-2390.

Wilkins, M. R., Appel, R. D., Van Eyk, J. E. \& 13 other authors (2006). Guidelines for the next 10 years of proteomics. Proteomics 6, $4-8$.
Zilm, P. S., Gully, N. J. \& Rogers, A. H. (2002). Growth pH and transient increases in amino acid availability influence polyglucose synthesis by Fusobacterium nucleatum. FEMS Microbiol Lett 215, 203-208.

Zilm, P. S., Gully, N. J. \& Rogers, A. H. (2003). Changes in growth and polyglucose synthesis in response to fructose metabolism by Fusobacterium nucleatum grown in continuous culture. Oral Microbiol Immunol 18, 260-262.

Edited by: R. J. Lamont 